\title{
EFISIENSI KANTOR CABANG BANK \\ (STUDI KASUS: KANTOR KAS BANK XYZ DI DKI JAKARTA)
}

\author{
THE EFFICIENCY OF BANK BRANCH OFFICE \\ (A CASE STUDY: XYZ BANK CASH OFFICE OF DKI JAKARTA)
}

\author{
Tri Maryono*)1, Machfud $^{* *)}$, dan Lukman M Baga $\left.{ }^{* * *}\right)$ \\ ${ }^{*}$ PT. Bank Tabungan Negara (Persero) Tbk \\ Jl. Gajah Mada, Jakarta 10130 \\ **) Departemen Teknologi Hasil Pertanian, Fakultas Teknologi Pertanian, Institut Pertanian Bogor \\ Jl. Lingkar Akademik. Kampus IPB Darmaga, Bogor 16680 \\ ${ }^{* * *}$ Departemen Agribisnis, Fakultas Ekonomi dan Manajemen, Institut Pertanian Bogor \\ Jl. Kamper, Wing 4 Level 5, Kampus IPB Darmaga, Bogor 16680
}

\begin{abstract}
This research aimed to analyze the technical efficiency of XYZ Bank Cash Office in DKI Jakarta. Factors affecting the efficiency level of cash office were also identified i.e. the building rental cost, work force cost, other operational costs, competence of cash office chief, and location of cash office. The performance efficiency was analyzed by Two Stage DEA Analysis using Variable Return to Scale (VRS) with an output maximization approach. Multiple regression technique using Ordinary Least Square (OLS) was utilized to determine the factors affecting the cash office efficiency level in 2015. The results of efficiency analysis showed that the average efficiency score of XYZ Bank cash office in DKI Jakarta in the period of 2013-2015 was relatively inefficient. The regression analysis identified that significant factors statistically affected the efficiency score of cash office in 2015 were the building rental and work force costs. Meanwhile, the other operational costs had no effects on the efficiency level. Dummy variables of cash office chief competence and cash office location affected the efficiency level of BTN bank cash office in DKI Jakarta at a significant rate of $(\alpha) 10 \%$. The technical efficiency of XYZ bank cash office in DKI Jakarta was still relatively low, yet it showed an increase in the period of 2013-2015. Cash Offices in different locations have different scores on efficiency level. The selection of qualified and competent human resources in their field and the right selection of cash office location will affect the success of community funding which later affects the office efficiency level.
\end{abstract}

Keywords: OLS, cash office, production approach, two-stage DEA

\begin{abstract}
Abstrak: Penelitian ini bertujuan menganalisis efisiensi teknis dari Kantor Kas milik Bank XYZ di wilayah DKI Jakarta. Selanjutnya mengidentifikasi faktor-faktor yang memengaruhi tingkat efisiensi dari kantor kas yaitu biaya sewa gedung, biaya tenaga kerja, biaya operasional lainnya, kompetensi kepala kantor kas dan lokasi kantor kas. Analisis kinerja efisiensi dilakukan dengan Analisa Two Stage DEA menggunakan Variable Return to Scale (VRS) dengan pendekatan maksimisasi output. Teknik regresi berganda menggunakan Ordinary Least Square (OLS) digunakan untuk mengetahui faktor-faktor yang memengaruhi tingkat efisiensi kantor kas pada 2015. Hasil analisa efisiensi memperlihatkan bahwa rata-rata skor efisiensi kantor kas bank XYZ di wilayah DKI Jakarta pada tahun 2013-2015 secara relatif masih belum efisien. Analisis regresi menunjukkan bahwa faktor-faktor yang signifikan secara statistik memengaruhi skor efisiensi kantor kas pada tahun 2015, yaitu biaya sewa gedung dan biaya tenaga kerja. Sementara itu, biaya operasional lainnya tidak memengaruhi tingkat efisiensi. Variabel dummy kompetensi kepala kantor kas dan lokasi kantor kas memengaruhi tingkat efisiensi kantor kas bank btn di wilayah DKI Jakarta pada tingkat signifikansi $(\alpha)$ 10\%. Efisiensi teknis kantor kas bank XYZ di DKI Jakarta relatif masih rendah namun menunjukkan peningkatan selama tahun 2013-2015. Kantor Kas pada lokasi yang berbeda memiliki rata-rata tingkat efisiensi yang berbeda-beda pula. Pemilihan SDM yang berkualitas dan kompeten dibidangnya dan pemilihan lokasi kantor kas yang tepat akan memengaruhi keberhasilan penghimpunan dana masyarakat sehingga dapat memengaruhi tingkat efisiensi kantornya.
\end{abstract}

Kata kunci: OLS, kantor kas, pendekatan produksi, two stage DEA

\footnotetext{
${ }^{1}$ Alamat Korespondensi:

Email: yon_tr@yahoo.co.id
} 


\section{PENDAHULUAN}

Persaingan antar bank dapat terjadi karena perebutan sumber daya yang produktif seperti giro, tabungan, deposito dan penyaluran kredit, kompetisi dalam upaya menarik nasabah sebanyak - banyaknya dengan berbagai hadiah dan program promosi, produk dan jenis layanan baru yang didukung dengan perkembangan tehnologi yang mampu menekan biaya produksi dan distribusi (Widyastuti dan Armanto, 2013).

Schaeck dan Čihák (2008) berpendapat bahwa kompetisi antarbank mampu berpengaruh positif terhadap tingkat kesehatan melalui transmisi efisiensi. Dalam penelitiannya, dilakukan pengujian terhadap dua hipotesis, yakni The Competition Efficiency Hypothesis dan The Competition-Inefficiency Hypothesis. Hasil pengujian menunjukkan bahwa hipotesis pertama dapat dibuktikan. Artinya, kompetisi mampu menstimulasi bank menjadi lebih efisien dengan menciptakan harga yang kompetitif atau sama dengan marginal cost pada pasar persaingan sempurna.

Boot dan Schmeijts (2005) berpendapat bahwa Korelasi negatif antara tingkat kompetisi dan efisiensi berdasarkan The Competition-Inefficiency Hypothesis dapat terjadi pada struktur perbankan dengan tingkat persaingan yang tinggi, loyalitas nasabah cenderung menurun sehingga hubungan antara nasabah dan bank menjadi kurang stabil dan lebih bersifat jangka pendek. Kondisi yang demikian selain dapat memicu munculnya permasalahan asymmetric information, juga menstimulus bank agar lebih fokus dan banyak mengeluarkan biaya pada kegiatan yang bertujuan untuk meningkatkan loyalitas nasabah.

Kalangan perbankan di Indonesia sedang sibuk memikirkan produktivitas kantor-kantor cabangnya karena pada era digital saat ini nasabah semakin jarang berkunjung ke kantor cabang sementara jumlah jaringan kantor bank terus bertambah. Banyak kantor cabang sepi pengunjung karena nasabah lebih suka bertransaksi melalui saluran elektronik seperti ATM, mobile banking maupun internet banking dan melambatnya pertumbuhan kredit selama 3 tahun terakhir (2013-2015) di Indonesia telah menekan pendapatan industri perbankan yang $75 \%$ nya masih disumbang oleh pendapatan bunga.
Menurut Karnoto (2016) setelah melewati musim kering likuiditas, dua tantangan yang kini dihadapi bankbank di Indonesia, yaitu pertama terus merangkaknya NPL. Berdasarkan data statistik Bank Indonesia tahun 2016, NPL perbankan meningkat dari $2.48 \%$ tahun 2015 menjadi 2.87\% per Februari 2016. Kedua, yaitu melonjaknya biaya operasional (Overhead Cost) yang ditanggung bank-bank karena ada periode dimana bank-bank berlomba memperluas saluran distribusi (delivery channel) terutama jaringan kantor fisik yang membutuhkan investasi dan menimbulkan biaya operasional yang lebih besar. Pada tahun 2015 ditengah kelesuan kredit perbankan, jaringan kantor masih bertambah 226 kantor menjadi 32.963 kantor. Sebelumnya pada kurun waktu 2007-2014 jumlah kantor bank bahkan sudah naik lebih dari dua kali lipat.

DKI Jakarta sebagai pusat pemerintahan dan bisnis memiliki jumlah dana masyarakat terbesar di Indonesia sehingga menjadi tempat perebutan antar bank. Berdasarkan data SEKDA-BI, pada tahun 2015 jumlah dana masyarakat di DKI Jakarta sebesar Rp2.090 trilyun merupakan 48,21\% dari total dana masyarakat yang dihimpun di Indonesia sedangkan tahun 2015 jumlah kantor bank yang beroperasi di DKI Jakarta sebanyak 4.056 kantor bank. Sedangkan Bank XYZ memiliki jumlah kantor di wilayah DKI Jakarta sebanyak 150 Kantor meliputi Kantor Cabang, Kantor Cabang Pembantu dan Kantor Kas atau 3,70\% dari total kantor bank.

Dengan banyaknya jumlah kantor tersebut diperlukan evaluasi terhadap produktivitas kantor yang dimiliki dan strategi yang tepat dalam pengelolaannya. Keberhasilan dalam strategi pengelolaan kantor di wilayah DKI Jakarta menjadi salah satu tolok ukur yang sangat penting dalam memenangkan persaingan perbankan khususnya dalam penghimpunan dana masyarakat.

Sejak tahun 2010 PT. XYZ gencar untuk melakukan pembukaan Kantor Kas baru guna mendukung kebijakan perusahaan untuk meningkatkan penghimpunan dana masyarakat. Masalah yang dihadapi dalam pengelolaan Kantor Kas adalah masih banyak Kantor Kas di DKI Jakarta yang belum menunjukkan kinerja yang diharapkan, yaitu 44\% telah BEP dan 56\% Kantor Kas belum BEP. Hal ini menandakan bahwa belum semua Kantor Kas yang beroperasi di DKI Jakarta telah menjalankan bisnis secara optimal. Analisis tingkat 
efisiensi terhadap Kantor Kas Bank XYZ menjadi hal yang sangat penting untuk mengukur apakah seluruh faktor input yang digunakan telah memberikan hasil output yang optimal. Dengan kondisi persaingan perbankan yang semakin kompleks, regulasi Bank Indonesia yang mensyaratkan pemenuhan Alokasi Modal Inti (AMI) untuk pembukaan jaringan kantor baru mengharuskan bank XYZ untuk melakukan upayaupaya lebih baik guna mengoptimalkan pengelolaan kantor kas yang dimiliki dengan memperhatikan faktor internal dan eksternal yang dapat memengaruhi kinerjanya.

Tujuan penelitian ini adalah mengukur tingkat efisiensi Kantor Kas PT. Bank Tabungan Negara (Persero) Tbk di wilayah DKI Jakarta dan tingkat efisiensi Kantor Kas pada lokasi yang berbeda serta untuk mengetahui faktorfaktor yang berpengaruh terhadap tingkat efisiensi Kantor Kas PT. Bank Tabungan Negara (Persero) Tbk di wilayah DKI Jakarta yaitu pengaruh biaya sewa gedung, biaya tenaga kerja, biaya operasional lainnya, kompetensi kepala kantor kas dan lokasi kantor kas terhadap tingkat efisiensi kantor kas.

Ruang lingkup penelitian ini adalah mengukur efisiensi teknis kantor kas bank XYZ di wilayah DKI Jakarta, dimana bank XYZ adalah bank yang bergerak disektor perumahan. Adapun definisi efisiensi teknis dalam penelitian ini adalah kombinasi antara kapasitas dan kemampuan unit ekonomi untuk memproduksi sampai tingkat output maksimum dari jumlah input dan tehnologi yang digunakan. Output yang dimaksud dalam penelitian ini adalah jumlah simpanan masyarakat dalam bentuk giro, tabungan dan deposito dan pendapatan fee based yang merupakan pendapatan operasional non bunga. Perhitungan efisiensi menggunakan pendekatan produksi yaitu Kantor Kas sebagai produser dana masyarakat dengan orientasi maksimalisasi output.

\section{METODE}

Pendekatan Penelitian ini adalah deskriptif dan jenis data yang digunakan adalah data kuantitatif. Penelitian dilakukan pada 112 Kantor Kas Bank XYZ di wilayah DKI Jakarta periode tahun 2013-2015. Jenis data yang digunakan dalam penelitian ini adalah data sekunder dan Studi Pustaka. Data skunder berasal internal Bank XYZ dari Laporan Neraca dan Laba-rugi yang diterbitkan oleh Kantor Kas, Kantor Cabang dan data yang berasal dari Unit Kerja Lainnya. Studi Pustaka berkaitan dengan aspek teoritis didapat melalui penelitian kepustakaan yaitu melalui jurnal, laporan publikasi, buku teks, majalah, internet dan pustaka lain yang relevan dengan yang dibahas dalam penelitian ini. Sebanyak 82 Kantor Kas dapat dilakukan pengolahan dan analisis data menggunakan DEA atau 73,21\% dari jumlah Kantor Kas dan 30 Kantor Kas tidak dapat dilakukan pengolahan dan analisis. Hal ini disebabkan adanya data variabel output yang bernilai nol, yaitu jumlah giro. Analisis DEA mensyaratkan semua variable input dan output bernilai positif sehingga data yang dapat dilakukan pengolahan dan pengukuran skor efisiensi serta dilakukan analisis regresi adalah sebanyak 82 Kantor Kas. Data yang digunakan dalam analisis regresi adalah data cross section tahun 2015 dengan pertimbangan bahwa program seleksi profesional hire baru berjalan awal tahun 2015 .

Metode analisis data dalam penelitian ini terdiri dari dua tahap (two stage DEA): Data Envelopment Analysis (DEA) pendekatan model Variable Return to Scale (VRS) maksimisasi Output untuk mengukur efisiensi teknis Kantor kas. Selanjutnya, dengan regresi berganda dengan menggunakan metode OLS (Ordinary Linear Square). Pengolahan data menggunakan software eViews 6 untuk mengukur besarnya pengaruh faktor internal yang meliputi biaya sewa gedung, biaya tenaga kerja, biaya operasional lainnya, kompetensi kepala Kantor Kas dan faktor eksternal, yaitu lokasi Kantor Kas terhadap tingkat efisiensi Kantor Kas. Adapun Variabel input dan output yang digunakan dalam penelitian ini pada Tabel 1 .

Giokas (2008) dalam penelitiannya juga menggunakan metode two stage DEA dalam mengukur efisiensi teknis kantor cabang bank komersial di Yunani, yaitu tahap pertama menggunakan analisis DEA pendekatan VRS dengan dua uji semi parametric dan satu uji Kolmogorov-Smirnov, tahap kedua menggunakan analisis regresi untuk melihat pengaruh perbedaan karakteristik kantor cabang meliputi profitabilias, ukuran dan kekuatan pasar.

Untuk mengukur pengaruh faktor-faktor yang memengaruhi kinerja efisiensi Kantor Kas digunakan pendekatan menurut Zenios et al. (1999) Faktor-faktor yang memengaruhi kinerja Kantor Cabang Bank adalah sebagai berikut:

1. Lingkungan Internal Kantor Cabang meliputi: penggunaan sumber dayanya, praktek manajerial, Kompetensi Personal dll. 
2. Lingkungan Eksternal Kantor Cabang meliputi: lokasi dimana kantor cabang berada.

3. Besarnya ukuran kantor cabang. Ukuran Kantor Cabang didasarkan pada kriteria banyaknya jumlah karyawan yaitu Kantor Cabang Kecil jika jumlah karyawan kurang dari 5 orang; Kantor Cabang Menengah jika jumlah karyawan 6-19 orang; Kantor Cabang Besar jika jumlah karyawan 20-40 orang.

Dalam penelitian ini diasumsikan bahwa kompetensi personal dan praktek manajerial dapat tercermin pada gaya manajerial dan kompetensi masing-masing Kepala Kantor Kas yang berasal dari proses seleksi yang berbeda.berdasarkan tiga kriteria hasil seleksi, yaitu Kepala Kantor Kas dari regular, talent pool dan profesional hire. Sebagaimana disampaikan bahwa Kompetensi sebagai suatu unsur dalam kinerja berdimensi luas mulai dari sistem input, proses, output dan outcome. Sehingga sebagai suatu sistem unsurunsur yang membentuk kinerja tersebut saling berkaitan dan tidak berdiri sendiri (Amir, 2015). Proses seleksi Kepala Kantor Kas pada Bank BTN dibagi dalam tiga kriteria, yaitu Program Talent Pool, Profesional Hire, Reguler.

Menurut Mathis dan Jakson (2011) rekrutmen adalah proses yang menghasilkan sejumlah pelamar yang berkualifikasi untuk pekerjaan di suatu perusahaan atau organisasi, sedangkan menurut Irawan et al. (1997) rekrutmen adalah suatu proses untuk mendapatkan tenaga yang berkualitas guna bekerja pada perusahaan atau instansi.
Kriteria lokasi kantor kas di wilayah DKI Jakarta dibagi dalam tiga kategori: Dilokasi bisnis seperti: di pusat-pusat perdagangan/pertokoan, di pusat kota atau di jalan-jalan utama suatu kota, di areal komersial dari perumahan yang sudah berkembang; Di dalam lokasi kompleks perumahan; Di lokasi mitra bisnis, misalnya Rumah sakit, Universitas, Kantor Pos dll.

Model rumus regresi yang digunakan dalam penelitian ini untuk mengetahui seberapa besar pengaruh biaya sewa gedung, biaya tenaga kerja, biaya operasional lainnya serta kompetensi kepala kantor kas dan lokasi kantor kas terhadap tingkat efisiensi Kantor Kas Bank XYZ. Adapun model rumus regresi yang digunakan adalah sebagai berikut:

$$
\begin{aligned}
& \mathrm{Y}=\mathrm{C} 1+\mathrm{C} 2 \log \mathrm{X} 1+\mathrm{C} 3 \log \mathrm{X} 2+\mathrm{C} 4 \log \mathrm{X} 3+ \\
& \mathrm{C} 5 \mathrm{D} 1 \mathrm{D} 4+\mathrm{C} 6 \mathrm{D} 2 \mathrm{D} 4+\mathrm{C} 7 \mathrm{D} 3 \mathrm{D} 4+\mathrm{C} \text { D } 1 \mathrm{D} 6 \\
& \mathrm{Y}=\text { Skor efisiensi } \\
& \mathrm{C} 1=\text { Konstanta } \\
& \mathrm{X} 1=\text { Biaya sewa gedung } \\
& \mathrm{X} 2=\text { Biaya tenaga kerja } \\
& \mathrm{X} 3=\text { Biaya operasional lainnya }
\end{aligned}
$$

Variabel Dummy Kompetensi Kepala Kantor Kas

D1 $=$ Reguler

D2 $=$ Profesional Hire

\begin{tabular}{|c|c|}
\hline Variabel input & Sumber data \\
\hline Biaya sewa gedung (amortisasi) & Perjanjian Sewa \\
\hline Biaya tenaga kerja & Laporan laba - rugi \\
\hline Biaya operasional lainnya (listrik\& Telepon) & Laporan laba - rugi \\
\hline Variabel output & Sumber data \\
\hline Giro (nominal) & Neraca \\
\hline Tabungan (Nominal) & Neraca \\
\hline Deposito (Nominal) & Neraca \\
\hline Pendapatan fee base & Laporan laba - rugi \\
\hline
\end{tabular}

D3 = Talent Pool

Variabel Dummy Lokasi Kantor Kas

D4 = Lokasi daerah bisnis

D5 = Lokasi daerah perumahan

D6 $=$ Lokasi di kantor mitra bisnis

Tabel 2. Variabel yang digunakan dalam analisis efisiensi 
Penggunaan log dalam model regresi adalah untuk memperbaiki keragaman data agar menjadi lebih linier dan dapat memberikan hasil analisis yang lebih baik. Variabel Dummy kompetensi kepala kantor kas dan Dummy lokasi kantor kas merupakan hubungan interaksi dalam model dikarenakan setiap kepala kantor kas dengan kompetensi yang berbeda (reguler, profesional hire, talentpool) tidak mungkin ditempatkan pada kantor kas yang sama.

Pengujian statistik yang dilakukan dalam penelitian ini adalah Uji t (Uji t digunakan untuk menentukan signifikansi suatu variabel bebas secara individual dalam memengaruhi variabel tidak bebas), Uji $\mathrm{F}$ (Uji F digunakan untuk menentukan signifikan atau tidaknya suatu variabel bebas secara bersama-sama dalam memengaruhi variabel tidak bebas). Pengujian asumsi klasik juga dilakukan pada penelitian ini yaitu Uji Multikolinearitas, Uji Heteroskedastisitas, Uji Autokolinearitas, dan Uji Normalitas.

Kantor kas merupakan salah satu jaringan kantor bank dibawah kantor cabang yang memiliki tugas utama untuk menghimpunan dana masyarakat dan menghasilkan pendapatan dari jasa layanan perbankan yang diberikan berupa pendapatan fee base seperti transfer antar bank, pembayaran tagihan-tagihan dll. Kantor cabang merupakan jaringan rantai pasok untuk menambah seluruh rantai nilai dan menyebarkannya kepada pelanggan (Gupta, 2012). Sebagai salah satu unit kegiatan ekonomi (UKE) manajemen perlu mengetahui hasil kinerja yang telah dicapai kantor kas selama menjalankan aktivitas usahanya dan faktor-faktor apa saja yang memengaruhi pencapaian kinerja tersebut. Pengukuran peformance dalam jaringan cabang bank adalah tugas yang sulit karena mereka terdiri dari cabang yang berbeda ukuran yang menawarkan produk dan layanan yang berbeda sementara mereka berada dan beroperasi di wilayah ekonomi yang berbeda (Tsolas dan Giokas, 2012). Bank dipaksa untuk mengevaluasi efisiensi dan efektivitas jaringan kantor cabang dalam rangka meningkatkan kinerja kantor cabang secara keseluruhan (Lofti et al. 2012). Singkatnya kantor cabang menjadi pusat laba dan kontributor penting untuk pada lini bawah perusahaan secara keseluruhan (Grifell-Tatje' dan Marques-Gou, 2008). Kinerja kantor kas salah satunya dapat diukur dari tingkat efisiensi yang telah dicapai dalam menjalankan usahanya pada suatu waktu tertentu. Suatu perusahaan termasuk bank dikatakan efisien apabila dapat menghasilkan output yang optimum dengan input yang tersedia.
Tingkat efisiensi diukur dengan skala $0-1$ artinya suatu perusahaan atau bank dikatakan efisien apabila output dibagi input mencapai skala 1 atau 100\%. Menurut Kumer dan Gulati (2010) kinerja dapat didefinisikan sebagai kombinasi yang tepat antara efisiensi dan efiktifitas sedangkan menurut Sharma et al. (2013) efisiensi teknis merupakan kombinasi antara kapasitas dan kemampuan unit ekonomi untuk memproduksi sampai tingkat output maksimum dari jumlah input dan teknologi. Pengertian efisiensi teknis secara umum dapat diartikan sebagai keberhasilan bank secara individu dan tolok ukur industri perbankan dapat dievaluasi pada efisiensi peer group perbankan.

Kantor kas dalam menghasilkan output berupa dana giro, tabungan, deposito dan pendapatan fee base menggunakan sumber daya yang dimiliki (input) berupa biaya sewa gedung, biaya tenaga kerja dan biaya operasional lainnya. Kantor kas sebagai unit kegiatan ekonomi pada bank yang tidak menjalankan fungsi sebagai intermediary karena tidak ada penyaluran kredit dan dengan asumsi bahwa tidak semua kantor kas telah beroperasional pada titik optimum maka dalam pengukuran tingkat efisiensinya dilakukan analisis DEA model VRS dengan pendekatan produksi dan maksimisasi output. Dalam pendekatan produksi, kantor cabang dianggap sebagai unit yang memberikan layanan kepada nasabah dalam bentuk transaksi atau jumlah rekening yang dihasilkan (Tsolas, 2010)

Pengukuran efisiensi disamping dilakukan terhadap keseluruhan jumlah kantor kas yang dimiliki oleh suatu bank juga perlu dilakukan pengukuran efisiensi kantor kas secara sektoral berdasarkan lokasi kantor kas tersebut berada sehingga dapat diketahui tingkat efisiensi pada masing-masing lokasi. Hal tersebut dimaksudkan sebagai bahan pengambilan kebijakan oleh manajemen dimasa mendatang terkait penempatan kantor kas baru, pemindahan lokasi atau penutupan.

Dalam mencapai kinerja efisiensi kantor kas tidak hanya dipengaruhi oleh faktor internal meliputi penggunaan sumber daya dan kompetensi kepala kantor kas tetapi dipengaruhi juga oleh faktor ekternal, yaitu lokasi dimana kantor kas berada. Untuk mengetahui seberapa besar faktor-faktor yang memengaruhi efisiensi kantor kas digunakan analiasa regresi berganda dengan pendekatan OLS. Penggunaan sumber daya dalam penelitian ini diasumsikan adalah semua biaya yang digunakan untuk menghasilkan output, yaitu biaya sewa gedung, biaya tenaga kerja dan biaya operasional 
lainnya. Sebagian besar penelitian terkait efisiensi kantor cabang dalam melakukan pengukuran efisiensi biaya, produksi dan profitabilitas tenaga kerja dan sumber daya tangible lainnya sering diperlakukan sebagai input (Balfour, 2015). Segmen bank ritel telah menghadapi tekanan persaingan pada harga produk dan jasa serta perkembangan tehnologi sehingga pemahaman operasional bank dan manajemen yang baik sangat penting dalam menjaga tingkat kompetitif bank (De Young, 2005; Berger and DeYoung, 2006; De Waal dan Coevert, 2007). Dengan mengetahui faktorfaktor yang memengaruhi efisiensi kantor kas maka akan dapat ditentukan kebijakan bagi manajerial dalam meningkatkan kinerja disetiap kantor kas maupun secara keseluruhan. Kerangka pemikiran konseptual penelitian ini dapat dilihat pada Gambar 1.

Berdasarkan latar belakang masalah, rumusan masalah, tujuan penelitian serta landasan teori maka hipotesis penelitian ini adalah sebagai berikut:
1. Biaya sewa gedung

H0 : Biaya sewa gedung tidak memiliki pengaruh negatif dan signifikan terhadap nilai efisiensi teknis kantor kas bank XYZ di Jakarta pada tahun 2015.

H1 : Biaya sewa gedung memiliki pengaruh negatif dan signifikan terhadap nilai efisiensi teknis kantor kas bank XYZ di Jakarta pada tahun 2015.

2. Biaya tenaga kerja

H0 : Biaya tenaga kerja tidak memiliki pengaruh negatif dan signifikan terhadap nilai efisiensi teknis kantor kas bank XYZ di Jakarta pada tahun 2015.

H1 : Biaya tenaga kerja memiliki pengaruh negatif dan signifikan terhadap nilai efisiensi teknis kantor kas bank XYZ di Jakarta pada tahun 2015 .

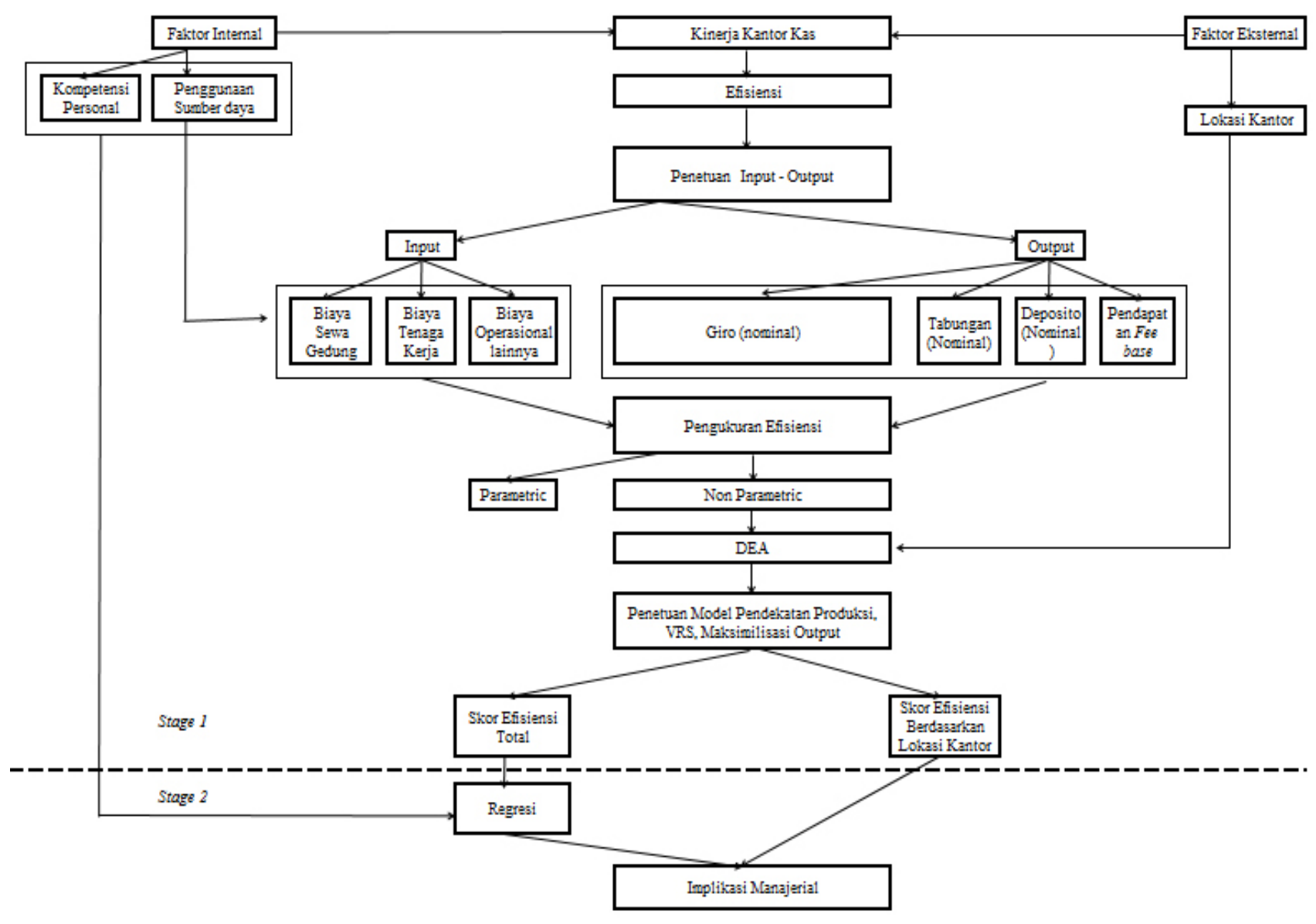

Gambar 1. Kerangka pemikiran penelitian 
3. Biaya oprasional lainnya

H0 : Biaya operasional lainnya tidak memiliki pengaruh negatif dan signifikan terhadap nilai efisiensi teknis kantor kas bank XYZ di Jakarta pada tahun 2015 .

H1 : Biaya operasional lainnya memiliki pengaruh negatif dan signifikan terhadap nilai efisiensi teknis kantor kas bank XYZ di Jakarta pada tahun 2015.

4. Perbedaan kompetensi kepada kantor kas dan lokasi kantor

H0 : Diduga perbedaan kompetensi kepala Kantor Kas dan lokasi kantor kas tidak berpengaruh signifikan terhadap nilai efisiensi teknis kantor kas bank XYZ di Jakarta pada tahun 2015.

H1 : Diduga perbedaan kompetensi kepala Kantor Kas dan lokasi kantor kas berpengaruh signifikan terhadap nilai efisiensi teknis kantor kas bank XYZ di Jakarta pada tahun 2015.

\section{HASIL}

\section{Hasil Pengukuran Efisiensi Kantor Kas di DKI Jakarta}

Analisis DEA mensyaratkan semua variable input dan output bernilai positif dan tidak boleh nol sehingga berdasarkan hasil pengolahan data terhadap 112 kantor kas di wilayah DKI Jakarta hanya sebanyak 82 kantor kas atau sebesar 73,21\% dari total kantor kas yang memenuhi syarat untuk dapat dilakukan Analisis DEA. Hasil rata-rata tingkat efisiensi Kantor Kas Bank XYZ di DKI Jakarta tahun 2013-2015, dimana rata-rata skor total efisiensi pada tahun 2013 adalah $69,29 \%$ dan meningkat menjadi $76,08 \%$ pada tahun 2015 dan sempat turun menjadi 68,13\% (Tabel 2). Naik turunnya tingkat efisiensi kantor kas disebabkan pengaruh naik turunnya jumlah dana simpanan nasabah yang dihimpun pada beberapa kantor kas di wilayah DKI Jakarta selama kurun waktu tiga tahun yaitu tahun 2013-2015. Secara umum Kantor Kas Bank XYZ di wilayah DKI Jakarta selama tahun 2013-2015 menunjukkan tingkat efisiensi yang masih relatif rendah walaupun cenderung meningkat artinya belum semua kantor kas di wilayah DKI Jakarta telah memproduksi dana simpanan nasabah secara optimum.
Hasil pengukuran efisiensi kantor kas dalam penelitian ini belum bisa dibandingkan dengan hasil penelitian lain karena sepanjang pengetahuan penulis belum ada analisis efisiensi sampai pada lingkup kantor kas, baru sebatas efisiensi pada level bank secara keseluruhan (bank wide) dan kantor cabang dengan variabel input dan output yang berbeda.

\section{Hasil Pengukuran Efisiensi Kantor Kas Di wilayah DKI Jakarta Berdasarkan Lokasi Kantor}

Perbandingan skor efisiensi kantor kas pada lokasi berbeda dapat dilihat pada Tabel 3. Rata-rata skor efisiensi kantor kas pada lokasi daerah bisnis menunjukkan perkembangan yang terus meningkat dari $66,16 \%$ tahun 2013 menjadi 75,00\% pada tahun 2015 sedangkan kantor kas di daerah perumahan rata-rata skor efisiensinya berfluktuasi dari 71,87\% tahun 2013 turun menjadi 67,74\% tahun 2014 sedangkan tahun 2015 meningkat kembali menjadi 76,18\%. Demikian juga kantor kas di daerah mitra bisnis dari 79,37\% tahun 2013 turun menjadi 63,46\% tahun 2014 dan meningkat kembali tahun 2015 menjadi 89,73\%. Hal ini menunjukkan bahwa kantor kas yang berada di lokasi daerah bisnis menunjukkan perkembangan lebih baik dibandingkan dengan kantor kas di daerah perumahan dan lokasi mitra bisnis karena memperlihatkan peningkatan secara terus menerus dibandingkan lokasi lain yang berfluktuasi tingkat efisiensinya.

Tabel 2. Distribusi skor efisiensi kantor kas di DKI Jakarta Tahun 2013-2015

\begin{tabular}{lccc}
\hline \multicolumn{1}{c}{$\begin{array}{c}\text { Distribusi } \\
\text { skor efisiensi (\%) }\end{array}$} & 2013 & 2014 & 2015 \\
\hline 100 & 27 & 25 & 29 \\
$91-99$ & 4 & 1 & 4 \\
$81-90$ & 7 & 8 & 4 \\
$71-80$ & 3 & 3 & 13 \\
$61-70$ & 9 & 10 & 11 \\
$51-60$ & 7 & 10 & 6 \\
$41-50$ & 6 & 4 & 6 \\
$31-40$ & 5 & 12 & 5 \\
$21-30$ & 9 & 8 & 3 \\
$11-20$ & 5 & 1 & 1 \\
$0-10$ & 0 & 0 & 0 \\
\hline Jumlah kantor kas & 82 & 82 & 82 \\
\hline Jumlah kantor kas yang & $32,93 \%$ & $30,49 \%$ & $35,37 \%$ \\
efisien (100\%) & & & \\
\hline Rata-rata total skor efisiensi & $69,29 \%$ & $68,13 \%$ & $76,08 \%$ \\
\hline
\end{tabular}


Tabel 3. Perbandingan prosentase jumlah kantor kas yang efisien dan rata-rata total skor efisiensi tahun 2013 2015 berdasarkan lokasi di DKI Jakarta

\begin{tabular}{lllll}
\hline Lokasi kantor kas & Keterangan & 2013 & 2014 & 2015 \\
\hline Daerah bisnis & Kantor kas - efisien (\%) & 24,39 & 29,27 & 29,27 \\
& Rata-rata total skor efisiensi (\%) & 66,16 & 68,84 & 75,00 \\
Daerah perumahan & Kantor kas - efisien (\%) & 39,47 & 31,58 & 39,47 \\
& Rata-rata total skor efisiensi (\%) & 71,87 & 67,74 & 76,18 \\
\multirow{2}{*}{ Kantor mitra bisnis } & Kantor kas - efisien (\%) & 66,67 & 33,33 & 66,67 \\
& Rata-rata total skor efisiensi (\%) & 79,37 & 63,46 & 89,73 \\
\hline
\end{tabular}

Lokasi kantor kas yang berbeda memiliki skor efisiensi yang berbeda-beda, hal ini sejalan dengan hasil penelitian Giokas (2008), bahwa tingkat efisiensi operasional kantor cabang bank di Yunani pada lokasi yang berbeda menunjukkan memiliki skor efisiensi yang berbeda-beda pula tergantung kondisi pada masingmasing lokasi kantor cabang bank ditempatkan.

\section{Penentuan Faktor-faktor yang Memengaruhi Efisiensi Kantor Kas Bank XYZ di Wilayah DKI Jakarta.}

Hasil analisis regresi berganda menggunakan pendekatan OLS menunjukkan bahwa setelah dilakukan pengujian statistik dan uji asumsi klasik, dapat diperoleh kesimpulan bahwa secara keseluruhan model persamaan regresi yang digunakan dalam penelitian ini telah memenuhi persyaratan BLUE (Best Linear Unbiased Estimator) untuk OLS. Nilai probabilitas F-Statistik $(0,000007)$ lebih kecil dari $\alpha$ sebesar 5\% sehingga $\mathrm{H} 0$ ditolak atau $\mathrm{H} 1$ diterima. Hal tersebut berarti, seluruh variabel independen secara bersamasama berpengaruh secara signifikan terhadap efisiensi kantor kas Bank BTN di Jakarta. Tabel 4 menunjukkan hasil perhitungan estimasi regresi dengan metode OLS. Hal ini menunjukkan bahwa secara keseluruhan biaya sewa gedung, biaya tenaga kerja, biaya operasional lainnya, kompetensi kepala kantor kas dan lokasi kantor kas berpengaruh secara signifikan terhadap efisiensi kantor kas di wilayah DKI Jakarta.

\section{Hasil Uji - t}

Hasil Uji-t menunjukkan bahwa koefisien masingmasing variabel bebas memiliki nilai yang berbeda. Identifkasi masing-masing variabel dijelaskan sebagai berikut:

a. Biaya sewa gedung, koefisien regresi variabel biaya sewa gedung (X1) terhadap efisiensi (Y) adalah $-21.97 \%$ dengan tingkat signifikansi (prob. sebesar
0.0001) mendekati 0\%. Dengan demikian, H0 ditolak atau $\mathrm{H} 1$ diterima.

b. Biaya tenaga kerja, Koefisien regresi variabel biaya tenaga kerja (X2) terhadap efisiensi (Y) adalah $-111,61 \%$ dengan tingkat signifikansi (prob. sebesar 0,0000). Dengan demikian, H0 ditolak atau H1 diterima.

c. Biaya operasional lainnya, Koefisien regresi variabel biaya operasional (X3) terhadap efisiensi (Y) adalah -6,71\%. Namun, tingkat signifikansinya sebesar 0,1716 atau lebih besar dari $\alpha$ sebesar $5 \%$. Dengan demikian H0 diterima atau H1 ditolak

d. Koefisien Dummy variabel untuk kompetensi kepala kantor kas dan lokasi kantor kas memiliki nilai probabilitas lebih besar dari $\alpha$ sebesar 5\%. Hal ini menunjukkan bahwa tidak terdapat perbedaan secara signifikan kompetensi kepala kantor kas dan lokasi kantor kas pengaruhnya terhadap efisiensi kantor kas pada tingkat signifikansi 5\%. Namun pada tingkat signifikansi $10 \%, \mathrm{D} 1 * \mathrm{D} 4$ (regular di lokasi bisnis) dan D2*D4 (profesional hire di lokasi bisnis) masing-masing memiliki nilai probabilitas 0,0720 dan 0,0998, hal ini berarti kedua variabel ini signifikan pada level signifikansi $10 \%$. Artinya D1*D4 (regular di lokasi bisnis) memiliki nilai efisiensi lebih tinggi $9,63 \%$ dibandingkan seluruh kantor kas di lokasi perumahan pada berbagai tingkat kompetensi kepala kantor kas. Sementara D2*D4 (profesional hire di lokasi bisnis) menunjukkan bahwa nilai efisiensinya lebih tinggi $14,73 \%$ dibandingkan seluruh kantor kas di lokasi perumahan pada berbagai tingkat kompetensi kepala kantor kas. Kompetensi kepala kantor kas dan lokasi kantor tidak signifikan pada $\alpha$ sebesar 5\% dapat diduga disebabkan data yang digunakan adalah data cross section tahun 2015 dan program seleksi kepala kantor dari talent pool dan professional hire baru berjalan 1 tahun sehingga hasil kinerja belum sepenuhnya dapat dilihat dan jumlah kepala kantor kas dari tiga kategori seleksi tidak seimbang dan penyebarannya tidak 
merata. Sejalan dengan penelitian Yullyanti (2009) yang dilakukan di Kantor Sekretariat Jenderal Departemen Energi dan Sumber Daya Mineral (DESDM) dengan salah satu tujuannya untuk mengetahui pengaruh pengaruh seleksi terhadap kinerja pegawai di Kantor Sekretariat Jenderal DESDM. Hasil penelitian menunjukkan bahwa secara signifikan terdapat pengaruh seleksi terhadap kinerja pegawai.Seleksi merupakan representasi dari indikator peserta seleksi, pelaku seleksi dan prosedur, ketiganya merupakan indikator terkuat untuk menduga kinerja pegawai. Indikator seleksi memberikan efek langsung terhadap produktivitas, mutu pekerjaan dan manajemen pekerjaan.

Hasil pengolahan data, diperoleh angka koefisien determinasi (R2) sebesar 0,375586. Hal ini berarti bahwa variasi variabel dependen (skor efisiensi) dapat dijelaskan sebesar $37,56 \%$ oleh variabel bebasnya yaitu biaya sewa gedung, biaya tenaga kerja, biaya operasional lainnya dan variabel Dummy kompetensi kepala kantor kas dan lokasi kantor kas sisanya dijelaskan oleh variabel lain yang tidak diketahui.

\section{Implikasi Manajerial}

Implikasi manejemen dalam penelitian ini adalah Tingkat efisiensi kantor kas dapat ditingkatkan dengan mengendalikan sisi input atau pengendalian biayabiaya yang digunakan dalam proses menciptakan output (dana masyarakat dan pendapatan fee base) yaitu mengantisipasi kenaikan biaya sewa gedung yang tinggi dengan melakukan proses negosiasi sewa jangka panjang atau melakukan pembelian gedung kantor dengan skala prioritas untuk kantor kas yang memiliki perkembangan kinerja yang baik, lokasi secara bisnis sangat strategis dan berkembang. Selanjutnya, Mendorong peningkatan produktivitas kerja setiap karyawan kantor kas dengan meningkatkan kontribusi dalam aktivitas penghimpunan dana melalui program employ get customer.

Dari sisi output, yaitu perlu adanya peningkatan produktifitas dalam penghimpunan dana masyarakat pada setiap kantornya minimal sama dengan rata-rata produktivitas per kantor cabang bank pemerintah yang ada di wilayah DKI Jakarta terutama peningkatan penghimpunan dana giro dan deposito.

Tabel 5. Hasil estimasi regresi

\begin{tabular}{|c|c|c|c|c|}
\hline Dependent Variable: & & & & \\
\hline Method: Least Squar & & & & \\
\hline Date: $01 / 03 / 17$ Tim & & & & \\
\hline Sample: 182 & & & & \\
\hline Included observation & & & & \\
\hline Variable & Coefficient & Std. Error & $t$-Statistic & Prob. \\
\hline $\mathrm{C}$ & 2813,692 & 462,7397 & 6,080506 & 0,0000 \\
\hline LOG(X1) & $-21,97219$ & 5,391584 & $-4,075276$ & 0,0001 \\
\hline $\operatorname{LOG}(\mathrm{X} 2)$ & $-111,6144$ & 21,82657 & $-5,113696$ & 0,0000 \\
\hline $\operatorname{LOG}(\mathrm{X} 3)$ & $-6,714822$ & 4,864075 & $-1,380493$ & 0,1716 \\
\hline $\mathrm{D} 1 * \mathrm{D} 4$ & 9,633871 & 5,277360 & 1,825510 & 0,0720 \\
\hline $\mathrm{D} 2 * \mathrm{D} 4$ & 14,72657 & 8,836534 & 1,666555 & 0,0998 \\
\hline $\mathrm{D} 3 * \mathrm{D} 4$ & $-1,756904$ & 14,90630 & $-0,117863$ & 0,9065 \\
\hline $\mathrm{D} 1 * \mathrm{D} 6$ & 19,61731 & 11,82094 & 1,659539 & 0,1012 \\
\hline$R$-squared & 0,375586 & Mean dependent var & & 76,08427 \\
\hline Adjusted R-squared & 0,316519 & S.D. dependent var & & 23,66292 \\
\hline S.E. of regression & 19,56282 & Akaike info criterion & & 8,877606 \\
\hline Sum squared resid & 28320,08 & Schwarz criterion & & 9,112408 \\
\hline Log likelihood & $-355,9819$ & Hannan-Quinn criter. & & 8,971876 \\
\hline$F$-statistic & 6,358720 & Durbin-Watson stat & & 1,774867 \\
\hline $\operatorname{Prob}(F$-statistic) & 0,000007 & & & \\
\hline
\end{tabular}


Strategi pemilihan lokasi yang tepat menjadi salah satu syarat bagi keberhasilan peningkatan kinerja efisiensi Kantor Kas. Penempatan SDM yang berkualitas dan kompeten dalam bidangnya dan ditempatkan pada lokasi kantor kas yang tepat akan menjadi faktor pendorong keberhasilan penghimpunan dana masyarakat pada kantor kas di wilayah DKI Jakarta yang pada akhirnya akan dapat meningkatkan tingkat efisiensinya. Program seleksi kepala kantor kas dari profesional hire dapat menjadi salah satu solusi untuk mempercepat program peningkatan kinerja efisiensi kantor kas.

\section{KESIMPULAN DAN SARAN}

\section{Kesimpulan}

Setelah dilakukan Analisis DEA diperoleh hasil ratarata skor efisiensi teknis Kantor Kas bank BTN di DKI Jakarta selama tahun 2013-2015 relatif belum efisien walaupun menunjukkan peningkatan dari 69,29\% pada tahun 2013 menjadi 76,08\% pada tahun 2015 dan sempat terjadi penurunan pada tahun 2014 menjadi $68,13 \%$. Kantor Kas pada lokasi yang berbeda memiliki rata-rata skor efisiensi yang berbeda-beda pula.

Hasil analisis regresi diperoleh hasil bahwa biaya sewa gedung dan biaya tenaga kerja secara signifikan memengaruhi skor efisiensi Kantor Kas bank BTN di DKI Jakarta pada tahun 2015 sedangkan biaya operasional lainnya tidak memengaruhi secara signifikan terhadap efisiensi kantor kas. Kompetensi kepala kantor kas dan lokasi kantor tidak signifikan memengaruhi efisiensi kantor kas pada level $\alpha=5 \%$ namun pada level signifikansi $10 \%$, Kepala Kantor Kas yang berasal dari profesional hire dan ditempatkan di lokasi daerah bisnis memiliki tingkat efisiensi paling tinggi dibandingkan kepala kantor kas dari reguler yang ditempatkan pada lokasi daerah bisnis.

Pemilihan SDM yang berkualitas dan kompeten dibidangnya dan pemilihan lokasi kantor kas yang tepat akan memengaruhi keberhasilan penghimpunan dana masyarakat sehingga dapat memengaruhi skor efisiensi kantornya. Pemilihan SDM salah satunya dapat dilakukan dengan program seleksi profesional hire.

\section{Saran}

Agar dapat memberikan hasil analisis yang lebih baik, dalam penelitian selanjutnya sebaiknya menggunakan data panel sehingga dapat memberikan jumlah pengamatan yang besar, meningkatkan degree of freedom (derajat kebebasan), data memiliki variabilitas yang besar, dapat memberikan informasi lebih banyak sehingga dapat memberikan hasil analisis yang lebih baik. Untuk menigkatkan Koefisien determinasi (R2), dalam penelitian selanjutnya dapat menambahkan variabel lainnya yang relevan dengan materi penelitian yang sejenis dengan penelitian ini.

\section{DAFTAR PUSTAKA}

Amir MF. 2015. Memahami Evaluasi Kinerja Karyawan, Konsep dan Penilaian Kinerja di Perusahaan. Jakarta: Mitra Wacana Media.

Boot AW, dan Schmeijts A. 2005. The competitive challenge in banking. Amsterdam Center for Law \& Economics Working Paper 2005-08.

Balfour R, Joo S-J, Whited HIH, Lin JW. 2015. Assessing the comparative performance of banking branches. Benchmarking:International Journal 22(5): 963-972. https://doi.org/10.1108/ BIJ-04-2013-0048.

Berger AN, DeYoung R. 2006. Technological progress and the geographic expansion of the banking industry. Journal of Money, Credit and Banking 38(6):1483-1513.https://doi.org/10.1353/ mcb.2006.0077.

De Waal AA, Coevert V. 2007. The effect of performance management on the organizational results of a bank. International Journal of Productivity and Performance Management 56(5/6):397-416. https://doi.org/10.1108/17410400710757114.

De Young R. 2005. The performance of internet-based business models: evidence from the banking industry. The Journal of Business 78(3): 893948. https://doi.org/10.1086/429648.

Giokas DI. 2008. Cost efficiency impact of bank branch characteristics and location. Managerial Finance 34(3): 172-185. https://doi. org/10.1108/03074350810848054.

Grifell-Tatje E, Marques-Gou P .2008. Internal performance evaluation: The case of bank branches. International Journal of Service Industry Management 19(3): 302-324. https:// doi.org/10.1108/09564230810874995. 
Gupta V.K. 2012. Flexible strategic framework for managing forces of continuity and change in retail banking business processes in India. Business Process Management Journal18(4): 553-575. https://doi.org/10.1108/14637151211253729.

Irawan P, Suryani SFMotok, Sri WKS. 1997. Manajemen Sumber Daya Manusia. Jakarta: STIA LAN Press.

Karnoto M. 2016. Nasib kantor bank pada era digital, Majalah Infobank No. 449/Mei 2016/Vol. XXXVIII

Kumer S, Gulati R. 2010. Measuring efficiency, effectiveness and performance of Indian public sectorbanks.InternationalJournalof Productivity and Performance Management 59(1): 51-74. https://doi.org/10.1108/17410401011006112

Lofti F.H, Eshlaghy A.T, Shafiee M, Saleh H. Nikoomaram H, Seyedhoseini S.M. 2012. A new two-stage data envelopment analysis (DEA) model for evaluating the branch performance of banks. African Journal of Business Management 6(24): 7230-7241.

Mathias RI, Jackson JH. 2001. Manajemen Sumber Daya Manusia. Jakarta. Salemba Empat.

Schaeck K, Čihák M. 2008. How does competition affect efficiency and soundness in banking. $\mathrm{E} C B$ Working Paper No. 932.
Sharma D, Sharma AK, Barua KM. 2013. Efficiency and productivity of banking sector : A critical analysis of literature and design of conceptual model. Qualitative Research in Financial Markets 5(2): 195-224. https://doi.org/10.1108/ QRFM-10-2011-0025.

Tsolas IE, Giokas DI . 2012. Bank branch efficiency evaluation by means of least absolute deviations and DEA. Managerial Finance 38(8): 768-785. https://doi.org/10.1108/03074351211239397.

Tsolas IE. 2010. Modeling bank branch profitability and effectiveness by means of DEA. International Journal of Productivity and Performance Management 59(5): 432-451. https://doi.org/10 $.1108 / 17410401011052878$.

Widyastuti RS, Armanto B. 2013. Kompetisi industri perbankan Indonesia. Buletin Ekonomi Moneter dan Perbankan 15(4): 417-439. https://doi. org/10.21098/bemp.v15i4.74.

Yullyanti, Ellyta. 2009. Analisis proses rekrutmen dan seleksi pada kinerja pegawai, bisnis \& birokrasi. Jurnal Administrasi dan Organisasi 16 (3): 131139.

Zenios CV, Zenios SA, Agathocleous K, Soteriou AC. 1999. Benchmarks of the efficiency of bank branches. Interfaces 29(3): 37-51. https://doi. org/10.1287/inte.29.3.37. 